\title{
Islamic Finance in Sub-Saharan Africa: Status and Prospects
}




\title{
Islamic Finance in \\ Sub-Saharan Africa: Status and Prospects
}

\author{
Enrique Gelbard, Mumtaz Hussain, Rodolfo Maino, \\ Yibin Mu, and Etienne B. Yehoue
}




\title{
IMF Working Paper
}

\author{
African Department
}

Development of Islamic Finance in Sub-Saharan Africa ${ }^{1}$

\author{
Prepared by Enrique Gelbard, Mumtaz Hussain, \\ Rodolfo Maino, Yibin Mu, and Etienne B. Yehoue
}

Authorized for distribution by Anne-Marie Gulde-Wolf

August 2014

\section{This Working Paper should not be reported as representing the views of the IMF.}

The views expressed in this Working Paper are those of the author(s) and do not necessarily represent those of the IMF or IMF policy. Working Papers describe research in progress by the author(s) and are published to elicit comments and to further debate.

\begin{abstract}
Islamic finance is a fast growing activity in world markets. This paper provides a survey on Islamic Finance in SSA. Ongoing activities include Islamic banking, sukuk issuances (to finance infrastructure projects), Takaful (insurance), and microfinance. While not yet significant in most Sub-Saharan countries, several features make Islamic finance instruments relevant to the region, in particular the ability to foster SMEs and micro-credit activtities. As a first step, policy makers could introduce Islamic financing windows within the conventional system and facilitate sukuk issuance to tap foreign investors. The entrance of full-fleged Islamic banks require addressing systemic issues, and adapting the crisis management and resolution frameworks. The IMF can play a role by sharing international experiences and providing advice on supervisory and regulatory frameworks as needed.
\end{abstract}

JEL Classification Numbers: F30 (International Finance) and G15 (International Financial Markets). Keywords: Islamic Finance, Islamic Banking, Sub-Saharan Africa

Authors' E-Mail Addresses: Egelbard@imf.org; Mhussain@imf.org; rmaino@imf.org; Ymu@imf.org, and Eyehoue@imf.org

\footnotetext{
${ }^{1}$ The authors thank Anne-Marie Gulde-Wolf, Ali Mansoor, Jemma Dridi, Juan Sole, Kareem Ismail, Khalid AlSaeed, Marco Piñon, Mauro Mecagni, Mohammed El Qorchi, Narayan Raman, Slavi Slavov, Magda Kandil, Domenico Fanizza, and Zeine Zeidane for valuable comments and suggestions and assume responsibility for any remaining errors. Naly Carvalho provided valuable research assistance.
} 


\section{Contents}

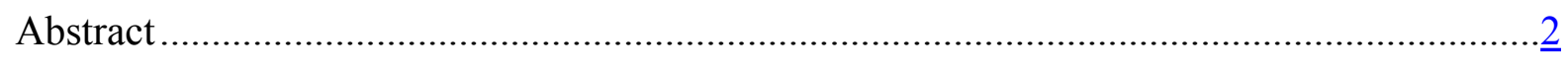

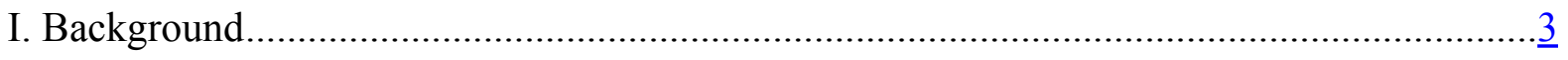

II. Status of Islamic finance in Sub-Saharan Africa ……….................................................

III. Developing Islamic Finance in Sub-Saharan Africa....................................................

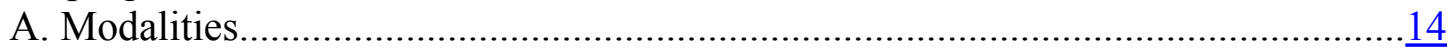

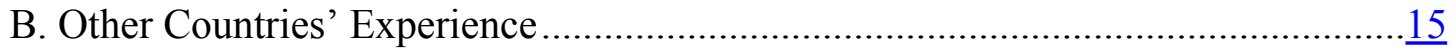

C. Developmental Strategies and Policy Issues..........................................................

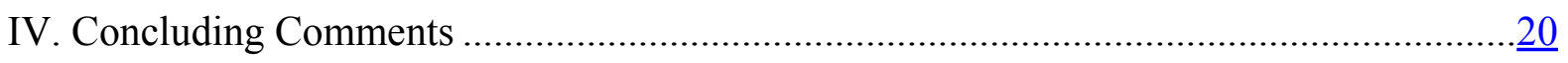

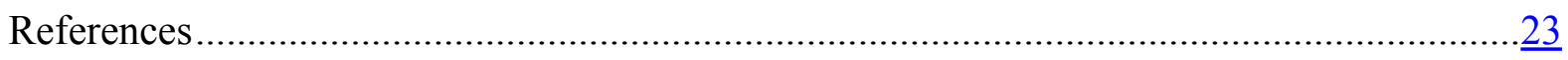




\section{BACKGROUND}

Islamic banking is a form of financial intermediation based on profit and loss sharing (PLS) and the avoidance of interest rate-based commitments and contracts that entail excessive risks and finance activities prohibited under Islamic principles (e.g. gambling and alcoholic beverages). Consequently, Shari'ah compliant investments follow the structure of an exchange of ownership in tangible assets or services where money's role is to facilitate the payment mechanism to implement the transfer. Moreover, risks are supposed to be shared among all parties: investors and entrepreneurs bear the business risk for a share in the profits. $^{2}$ This contrasts with conventional banking where transactions involving interest payments are common (Chong and Liu, 2009, Kahf, Ahmad, and Homud, 1998).

Under the PLS paradigm, an ex-ante lending rate in financial contracting is replaced by a rate of return determined ex-post on a profit-sharing basis. Only the profit sharing ratio between the capital provider and the entrepreneur is determined ex-ante. It is also possible for more than two parties to pool resources for investment (Chong and Liu, 2009). Such transactions do entail a number of risks but by their nature they limit asymmetric risk and moral hazard, while equity-based financing and prohibition of speculation limit risks on the asset side of a bank's balance sheet. While a downturn in the real economy affects profitability of Islamic banks, their ability to share this risk with depositors provides a cushion against excess leverage in the financial system. ${ }^{3}$ In addition, Islamic banks are required to know the project and use of funds, leading to close relationships with entrepreneurs and the likelihood that funds are allocated for the stated investment.

The market for Islamic financial assets has grown at an annual average rate of about 16 percent since 2006. Starting with a handful of institutions and negligible amounts in the late 1970's, Islamic finance grew to about 350 institutions and total assets of about US\$1.7 trillion in 2013 (Figure 1). ${ }^{4}$ Concentrated in Malaysia and Gulf Cooperation Council

\footnotetext{
${ }^{2}$ European Central Bank (2013) presents examples of Islamic financial contracts and their underlying characteristics and risks.

${ }^{3}$ Mirakhor and Krichene (2009) noted that the housing bubble before 2008 was to a large extent fuelled by the securitization of assets and credit derivatives which pushed excessive liquidity to the sub-prime markets and led to an extremely high leverage ratio in relation to real GDP. In the aftermath of the financial crisis, empirical evidence has supported the relative stability of Islamic financial system. Cihák and Hesse (2010), based on "z-scores" analysis, proved that Islamic financial system is financially stronger and less risky than conventional banks, though difference between large Islamic and conventional banks was not significant. Dridi and Hasan (2011) as well as and Abedifar et. al. (2013) noted that Islamic banks have been less affected by the 2008 crisis because they are not allowed for ethical reasons to invest in excessively risky instruments such as credit default swaps, leading to better credit and asset growth performance compared to conventional banks.

${ }^{4}$ The concept of Islamic banking is ancient, but its contemporary form is recent. Some forms of Islamic banking activities could be traced back to the eighth century, where the concept of deposits was well known in Baghdad (Iraq), Damascus (Syria), Cordoba — Capital of Spanish Muslim dynasty of the Ummayads (756-1031) — and Fez (Morocco). In Africa, Egypt developed the first Islamic transactions in 1890 for the construction of the
}

(continued...) 
countries, Islamic finance has expanded throughout the Middle East, Indonesia, the United Kingdom, North Africa, and, more recently, in some Sub-Saharan African countries. Despite this growth, however, Islamic financial assets make up under 1 percent of the world's financial assets.

The industry has set up international regulatory institutions to guide operations around the world, although it has been difficult to ensure standardization of Islamic products across different countries. The Accounting and Auditing Organization for Islamic Financial Institutions (AAOIFI), based in Bahrain, issues international standards on accounting, auditing, and corporate governance, while the Islamic Financial Services Board (IFSB), based in Malaysia, is in charge of standards for supervision and regulation.

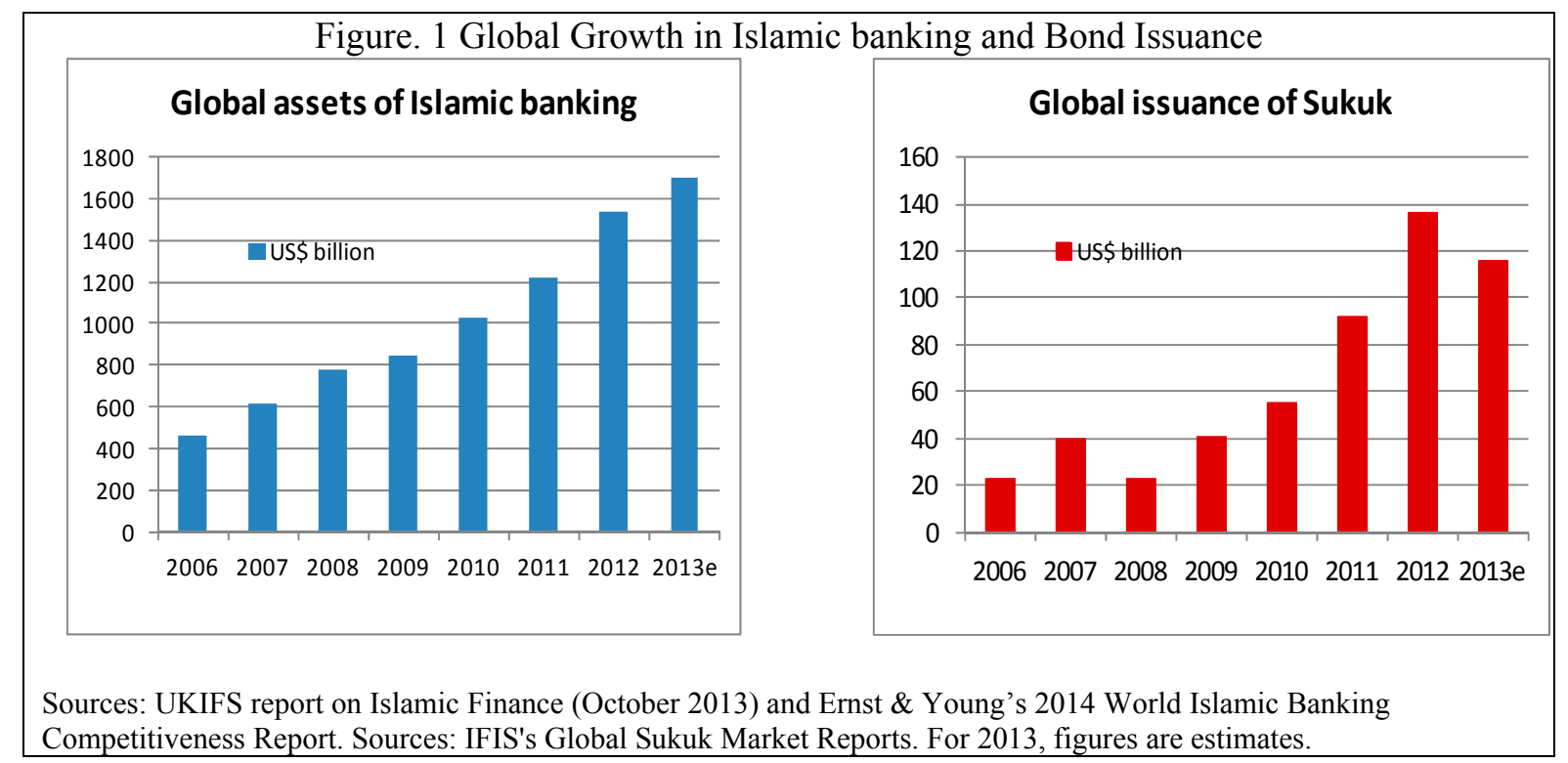

Some factors appear to be correlated with the diffusion of Islamic banking, namely the principles of risk-sharing that underlie financing, the growth of oil-rich economies, the presence of Muslims in the population, an enabling legal framework, and economic integration with Middle Eastern countries or proximity to Islamic financial centers (Imam and Kpodar, 2010; Ilias, 2010; Alam, 2012). A key driver behind interest in Islamic finance today is the possibility of tapping the international sukuk market, which does not require a domestic Islamic financial system (e.g., Japan has issued sukuk, as well as many other

Suez Canal. Contemporary Islamic banking institutions emerged in the 1960s with the Myt Ghamr Saving Bank in Egypt, followed by the Islamic Development Bank in Saudi Arabia and the Dubai Islamic Bank in the United Arab Emirates in the 1970s (Kahf, Ahmad, and Homud, 1998). In Sub-Saharan Africa, South Africa pioneered the development of Islamic financial instruments with one of the largest international Islamic banking conglomerates, Al-Baraka Banking Group in 1990s. 
countries). At the same time, the development of Islamic banking in some countries might facilitate risk sharing and improve financial inclusion.

Islamic banks have an array of modalities and financial instruments (Box 1). Nevertheless, some types appear more predominantly than others and financial institutions tend to combine aspects of different instruments to tailor different transactions. Murabaha - a modality by which a bank buys goods and sells to a customer on a deferred basis - and other debt-based financing appear to be dominant in the asset portfolios of Islamic banks. ${ }^{5}$ Murabaha and other mark-up instruments represent about 86 percent of financing in Islamic banks in the Middle East and North Africa, 70 percent in East Asia, 92 percent in South Asia, and 56 percent in Sub-Saharan Africa (Dusuki, 2007; Lewis, 2008). ${ }^{6}$ Sukuk bonds, which accounted for nearly US $\$ 120$ billion in 2013, have increasingly become a popular vehicle for infrastructure financing, including by sovereigns. Malaysia has been a leader in Sukuk issuing, although Gulf States (especially Saudi Arabia) are picking up the pace. One key reason investors mention for the appetite for sukuk is that it offers an opportunity for diversification. Conventional sukuk holders also report being comforted by the fact that the Islamic banks who invest alongside them tend to hold their investments until maturity, creating a more stable investment for everybody else. ${ }^{7}$

Islamic financing can only be extended to productive activities, trade, and real assets. While some debt possibilities are feasible, a strong preference is attached to risk sharing modes of finance. In particular, Islamic banking does not allow the creation of debt through direct lending and borrowing because credit can only be provided through lease or sale-based financing (Chapra, 2011). Even in these cases, Islamic financial principles demand that the asset sold or leased should be real and that the seller or the lessor should own this asset before the transaction. Moreover, the debt created from such sale or lease transactions cannot be sold to a third party to avoid the risk associated with it. These requirements make the lender take responsibility for risk or debt financing, thus helping prevent excessive risk and debt accumulation.

\footnotetext{
${ }^{5}$ Islamic banks have been concentrating on short-term trade finance, which is less risky. Instruments supporting short-term trade finance are therefore more predominant because less risky compared to instruments supporting for example entrepreneurial ventures, which in general tend to be riskier (Ariff, 1988).

${ }^{6}$ A study of Islamic banking behavior towards small firms in Sudan points to evidence indicating that the sector uses Murabaha financing rather than profit and loss sharing instruments to finance small firms (Ibrahim, 2010). A cross country analysis - including Sudan, United Arab Emirates, Kuwait, Bahrain, Jordan, and Egypt—also concludes that Islamic banks have a preference for trade finance (Khan, 1983).

${ }^{7}$ See for example Chadbourne \& Parke LLP (2013) “Islamic Bonds Go Mainstream”, October, available at http://www.chadbourne.com/IslamicBondsMainstream-Stevens_projectfinance/
} 
Following stringent sale requirements ("don't sell what you don't have") and the need to avoid unethical investments and harmful contracts (zarar), the Islamic mode of financing differs from conventional banking activities like debt swaps, short selling, collateralized debt obligations, and most derivatives. Similarly, there is a clear prohibition on earning profit from gambling (mayseer), in particular when uncertainty prevails and there are attempts to gain from speculation. While risks in any financial contract or arrangement are present, it is the excessive uncertainty and attempts to gain from such uncertainty via speculation that is restricted. Another principle that limits speculation is sharing of risks of financial contracts instead of risk transfer. A central concept in Islamic banking and finance is justice, which is achieved mainly through the sharing of risk (Dridi and Hasan, 2011). ${ }^{8}$

While Islamic finance offers some benefits, it is also subject to a number of constraints, most notably transaction costs and difficulties involved in supervising and monitoring. ${ }^{9}$ This has highlighted the importance of ensuring standardization and improving regulation. ${ }^{10}$ Despite the critical role that the AAOIFI and IFSB are playing, further work is needed to ensure compliance, including a transparent and credible assessment process for evaluating compliance with standards. ${ }^{11}$ In addition, internal boards at financial institutions and standard setting bodies could focus on training, oversight and internal compliance audits.

While Islamic finance has been documented in other regions of the world, little is written about its development in the SSA. Islamic finance remains small in SSA, although it has

\footnotetext{
${ }^{8}$ Similar to conventional banking, Islamic financing also places a strong emphasis on socially responsible transactions, guided by values that promote ethical finance and responsible investment. Deceptive sales or transactions, where known defects in a product are not conveyed to the buyers, are prohibited. Such deception rule is also applicable on disclosing all risks involved in financial transactions.

${ }^{9}$ By design, Islamic finance instruments are more expensive than conventional financing instruments offering the same services, wherever both are available. The sharing of risks and returns means that investors would demand credible evidence of the viability and return on an investment. This raises the cost to intermediation from information asymmetry between investors and entrepreneurs and requires more careful scrutiny of an investment's return by banks as an intermediary relative to conventional collateralized lending.

${ }^{10}$ The main problems are different legal interpretations of principles across countries (for example, a number of Islamic finance products approved in Malaysia are not accepted in Middle East countries). These obstacles prevent standardization and carry the risk that a negative signal about the products being Shari'ah compliant could affect them. Standardization has advantages: (i) new entrants can use products of existing institutions; (ii) makes it easier for participants to understand the products and evaluate risks and returns; (iii) potential for fewer disputes about compliance with Shari'ah; (iv) helps define tax treatment of products (this is especially important in dual systems with separate regulatory and supervisory frameworks); and (v) facilitates secondary trading and liquidity management, especially with Sukuks (Mohieldin, 2012).

${ }^{11}$ The AAOIFI has 41 accounting and governance guidelines for Islamic institutions. While regulators in Bahrain, Qatar, Syria and Sudan made these standards mandatory for Islamic financial institutions, most other countries considered the AAOIFI standards advisable (for example, in Malaysia, Saudi Arabia and the United Arab Emirates). Similarly, the IFSB has issued a number of regulatory and prudential standards, already adopted by a number of countries.
} 
potential given the region's demographic structure and prospects for financial deepening. This paper, therefore, aims to survey the current state of play in Islamic finance in the region and highlights some strategies or factors for its development.

In the remainder of this paper, we examine the status and potential of Islamic finance in SubSaharan Africa (Section II) and what lies ahead for those countries that wish to introduce these activities and the related policy issues (Section III). Section IV concludes. 


\section{Box 1. Islamic Financing: Modes and Instruments}

Resource Mobilization: Resources are typically mobilized from shareholders and savers. Shareholders are owners of the bank's equity while savers participate in the investments by providing funds on the basis of return sharing. Savers or depositors are considered as co-owners of funds for investment operations. Thus a deposit agreement is not a lending contract but rather a contract to provide funds that will be managed by the bank on behalf of the depositor (funds' owner). There are three ways to mobilize savings:

a) Investment deposits. These deposits share the net return on investment in proportion of the amount deposited and based on a contracted ratio which depends on the maturity of the investment.

b) Demand or current account deposits. These represent guaranteed liabilities but earn no return.

c) Bonds. A third way used to mobilize savings is through the issuance of Sukuk, which are Islamic bonds representing undivided shares in the ownership of tangible assets such as debt (Sukuk Murabaha), asset (Sukuk Al Ijara), project (Sukul al Istisna), or investment (Sukuk al Isthithmar).

Resource Allocation: Islamic banking makes use of resources mainly through three broad categories.

a) Sharing modes. There are two forms: (i) full partnership (Musharaka) is like a joint venture whereby both bank and providers of funds (investment, letter of credit, purchase of real estate) can participate in the management of the project (a modified version called diminishing Musharaka used mainly in housing allows clients to progressively acquire ownership); and (ii) non-voting or passive partnership (Mudaraba) is like equity finance whereby one party provides funds while the other provides expertise and management. With these modes of financing, accrued profits are shared on a pre-agreed basis.

b) Sale modes. They involve several forms, the most common being (i) a form of trade credit whereby a client requests the bank to purchase an item for her and the bank resells it to her for a predetermined price usually paid in installments (Murabaha); and (ii) deferred delivery purchase (Bay'salam, including Istisna') which is generally an agricultural contract that provides farmers with funds against future delivery of grain or output at the end of the season.

c) Leasing modes. Lease or lease-purchase agreements (Ijara/Ijara wal iqtina'), whereby the bank buys an item for a customer who then leases the item. This structure is used in Islamic mortgages and other business investments (e.g. Emirates Airlines has used Ijara to finance its expansion)

\section{Other Instruments}

- Bai'muajjal. Deffered payment or credit sale also known as Murabaha Mauajjal, whereby the seller notifies the buyer the cost and selling price and the final payment date (may be installments or lump sum); spot price may be lower than deferred payment price.

- Muswama. Standard market sale with no obligation of cost disclosure (i.e. the profit margin is hidden from the buyer).

- Jiala. Service charge, consultancy fee, placement fee, etc.

- Qard al Hasana. zero-interest loans; repaid when or if able, usually only to the needy.

Sources: Kahf, Ahmad, and Homud (1998); El Gamal (2006); Khan (2010). 


\section{Status OF Islamic FinanCe in SUb-Saharan Africa}

The financial sector in some SSA countries has been growing rapidly in the past two decades. New products have been introduced and financial institutions are playing an increasing role in financial intermediation, including cross-border financial flows (Table 2).

Table 2. Sub-Saharan Africa: Financial Deepening Indicators

\begin{tabular}{|c|c|c|c|c|c|c|c|c|c|}
\hline & \multicolumn{3}{|c|}{ Low-income countries } & \multicolumn{3}{|c|}{ Middle-income countries } & \multicolumn{3}{|c|}{$\begin{array}{c}\text { Middle-income countries } \\
\text { without South Africa }\end{array}$} \\
\hline & 1990-99 & $2000-04$ & $2009-11$ & 1990-99 & $2000-04$ & $2009-11$ & 1990-99 & $2000-04$ & $2009-11$ \\
\hline Bank deposits/GDP & 13.6 & 18.0 & 31.3 & 44.5 & 50.7 & 65.3 & 29.7 & 29.2 & 54.0 \\
\hline Private sector credit/GDP & 12.3 & 13.3 & 19.0 & 52.1 & 64.0 & 66.4 & 21.5 & 21.0 & 29.0 \\
\hline $\mathrm{M} 2 / \mathrm{GDP}$ & 21.9 & 26.9 & 32.0 & 49.8 & 55.6 & 70.1 & 35.0 & 32.1 & 44.1 \\
\hline Liquidity liabilities/GDP & 19.1 & 23.8 & - & 47.9 & 53.4 & - & 34.5 & 32.5 & - \\
\hline
\end{tabular}

However, Islamic finance in SSA remains small, although it has potential given the region's demographic structure and potential for financial deepening (Figure 2). As of end-2012, about 38 Islamic finance institutions - comprising commercial banks, investment banks, and takaful (insurance) operators - were operating in Africa. ${ }^{12}$ Out of this, 21 operated in North Africa, Mauritania and Sudan, and 17 in Sub-Saharan Africa. ${ }^{13}$

Figure 2. Global Islamic Finance Assets:

Geographical Breakdown, 2012 (US\$ billions)

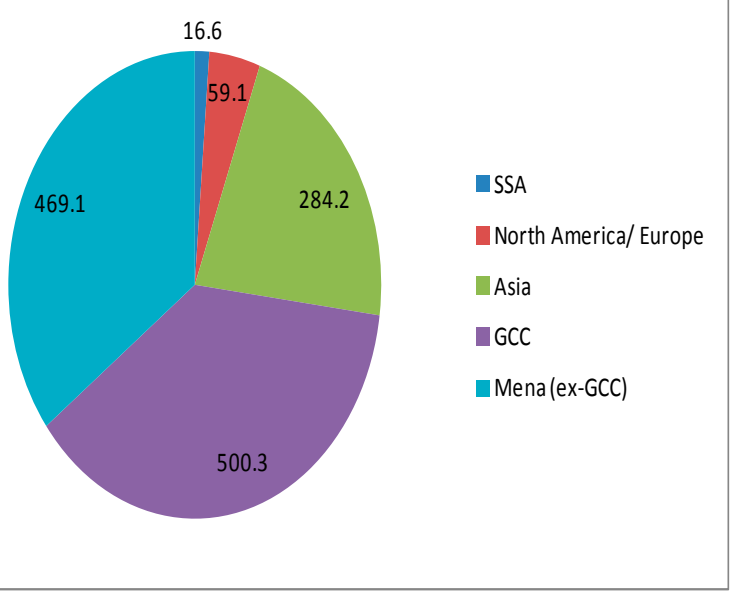

Source: European Central Bank (2013)
Figure 3. Islamic Banking in SSA

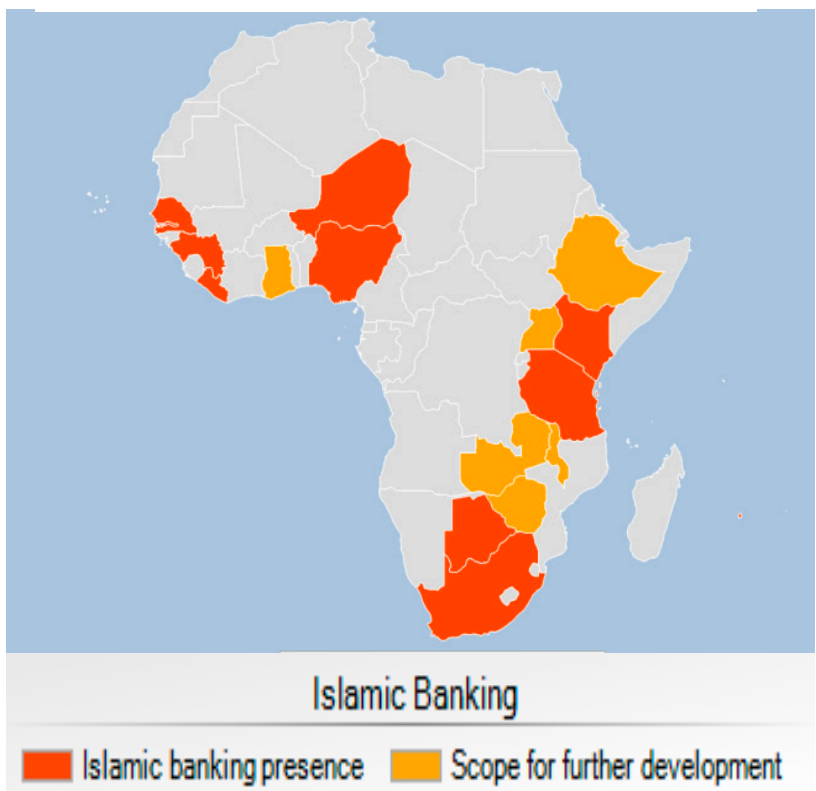

\footnotetext{
${ }^{12}$ Dow Jones Islamic Market Indexes, Quarterly Newsletter, July 2012.

${ }^{13}$ Estimates based on Bankscope and Zawya, April 18, 2012.
} 
Botswana, Kenya, Gambia, Guinea, Liberia, Niger, Nigeria, South Africa, Mauritius, Senegal and Tanzania have Islamic banking activities. ${ }^{14}$ There is also scope for development in Zambia, Uganda, Malawi, Ghana and Ethiopia, as all but Zambia have relatively large Muslim populations - Zambia is interested in using Islamic finance instruments to fund investment in the mining sector (Figure 3). In Uganda, the central bank has started the process of amending its banking regulations to allow for the establishment of Islamic banks and three Islamic banks have applied for a license. ${ }^{15}$ In particular, four countries have considerable potential for becoming a regional hub of Islamic finance activities:

- $\quad$ South Africa: Despite its relatively small Muslim population (1.5 percent), South Africa was the first Sub-Saharan African country to establish itself as a potential hub for Shari'ah-compliant banking in the region. In 1989, Al Baraka—part of the Saudi Arabian-based Dallah Al Baraka group — and the Islamic Bank were the first Islamic banks granted licenses by the South African Reserve Bank. Although Islamic Bank was liquidated in 1998 owing to corporate governance issues, in 2004, WesBank launched an Islamic window, the WesBank Motor Vehicle and Asset Finance, followed by First National Bank with an Islamic window operating in deposits and transactional banking. In November 2005, the bank ABSA also launched an Islamic window. Other Islamic finance institutions in South Africa are Oasis Crescent Equity Fund, Symmetry Islamic Fund, Element Islamic Equity Fund, and Stanlib Shari'ah Equity Fund (Buksh, 2006 and Gulf African Bank, 2010). South Africa is expected to launch its first sukuk Islamic bond this year, as it seeks to diversify its debt obligations. ${ }^{16}$

- Nigeria: Although Nigeria hosts the largest Muslim population in Sub-Saharan Africa, (about half of its 170 million people), Islamic banking is still undeveloped in the country. Habib Bank (now Bank PHB) was the first bank operating an Islamic banking window (in 1992). Recently, there has been a new impetus to develop Islamic banking with the introduction of the Law Governing the Operation of Islamic

\footnotetext{
${ }^{14}$ In Guinea, the Islamic Bank of Guinea (BIG) — established in 1983-has assets for about \$44 million as of end-2013 (5 percent of total banking system assets) and operates as a conventional bank. In Senegal, the banking sector is regulated by the common WAEMU banking sector laws, which allow conducting banking activities based on Islamic principles (clarifications on the application of the general banking law to Islamic banking are being developed at the WAEMU level). In Niger, Islamic banking amounts to approximately US\$40 million (less than 3 percent of total assets in the banking system).

${ }^{15}$ In Uganda, three Islamic banks have applied for license and the central bank is amending regulations to allow for establishment of Islamic banks while Senegal launched an Islamic bond debt (Sukuk) to be issued on the sub-regional market during 2014 by the Senegal Islamic Bank. In Ethiopia, Zemzem Bank plans to be the country's first Islamic bank. See Zawya, "Islamic Banking in Africa," March 02, 2012; and Opalesque (Islamic Finance Briefing), February 16, 2011.

${ }^{16}$ Bloomberg news February 26, 2014.
} 
Banks by the Central Bank of Nigeria (CBN) in March 2009. CBN has also set up a Advisory Council of Experts for Islamic Finance. In June 2011, CBN issued the latest guidelines for non-interest banking and approved a banking license for Jaiz International Bank, the country's first full-fledged Islamic bank, which became operational in 2012. Diamond Bank has also started the process of establishing an Islamic banking window. ${ }^{17}$

- Kenya: Islamic banking emerged in Kenya with Barclays launching Islamic banking products in December 2005. ${ }^{18}$ The sector later expanded with the introduction of two Islamic banks, First Community Bank in 2007 and Gulf African Bank (GAB) in 2008. Other conventional banks such as Kenya Commercial Bank now offer Shari'ah compliant products through special Islamic windows. In 2010, through the Finance Act, the Kenyan authorities amended Section 45 of the Central Bank of Kenya Act to allow the Central Bank as the government's fiscal agent to recognize the payment of a return rather than interest on government securities, thereby opening up the spectrum of Shari'ah compliant investments in the country (Ndung'u, 2011). In 2013, Standard Chartered Bank has introduced an Islamic banking window in Kenya, adding to an existing window and two full-fledged Islamic banks operating in Kenya. As of end2013, Islamic banking accounts for two percent of the total banking business in Kenya.

- Mauritius: Islamic banking has been present in Mauritius since 1998 when the small Muslim community of the island started receiving services from the Al Barakah Cooperative Society Limited, an Islamic cooperative credit union, which offers tailormade Murabaha schemes, Hajj saving accounts, and Istisna' financing. In 2007, the Banking Act was amended to formally allow for Islamic banking activities and amendments were brought to the Finance Act 2008 to allow multiple payments of duties under Islamic mode of financing land and property and to allow global investments and Shari'ah compliant funds with net asset value of US\$75 million. Subsequently, HSBC Bank Mauritius launched Islamic banking products in the first half of 2009, becoming the first conventional bank offering such services. ${ }^{19}$ Also in 2009, the Bank of Mauritius granted an Islamic banking license to Century Banking Corporation, making it the country's first full-fledged Islamic bank (as of end-2012, the bank had $\$ 9.3$ million, representing less than one percent of total assets in the banking sector). In October 2010 India's Tata launched the Tata Indian

\footnotetext{
${ }^{17}$ Arab News, "Nigeria Opens Market for Islamic Finance," April 13, 2009; Zawya, "Islamic Banking in Africa," March 2, 2012.

${ }^{18}$ Panapress, December 20, 2005.

${ }^{19}$ HSBC closed its Islamic window in October 2012.
} 
Shari'ah Equity Fund through Tata Asset Management (Mauritius) Private Limited (TAMM) for investment in Shari'ah compliant equity or equity-equivalent listed Indian companies. The domiciliation of the Fund in Mauritius is the result of the Bank of Mauritius's efforts to position the island as a Shari'ah compliant hub. ${ }^{20}$

Notwithstanding its presence in a number of countries, Islamic finance is still at a nascent stage of development in SSA. The share of Islamic banks is still small, and Islamic capital markets are virtually nonexistent (there were small Sukuk issuances in Gambia and Nigeria). ${ }^{21}$ At the same time, the demand for Islamic finance products is likely to increase in coming years. At present, about half of the region's total population remains to be banked. Furthermore, The SSA Muslim population, currently at nearly 250 million people, is projected to reach 386 million in 2030 and financial activities are expected to rise as a share of GDP. ${ }^{22}$ It is also expected that many countries will introduce Islamic finance activities side-by-side conventional banking. Opportunities for the development of Islamic finance are expected to comprise retail products to small and medium-sized enterprises. The subcontinent's growing middle class, combined with its young population is an opportunity for Islamic finance to expand its services. ${ }^{23} \mathrm{SSA}$ 's large infrastructure needs will also provide an opportunity for Sukuk issuance to channel funds from the Middle-East, Malaysia, and Indonesia. For example, recent issuance of a Shari'ah-compliant bond by Osun state in Nigeria could start a trend in favor of sukuk, especially if planned sukuk by Senegal and South Africa materialize in 2014.

The development of Islamic Finance could also facilitate financial deepening by increasing the depth and breadth of intermediation, extending the reach of the system (e.g. extension of maturities and facilitation of hedging and risk diversification). At the same time the much larger non-Muslim population could find Islamic financial instruments attractive in broadening the range of available options, particularly for SMEs and micro-credit. Moreover, financial deepening and inclusion could be further enhanced if new instruments are inspired from Islamic finance, but without necessarily being Shari'ah certified. The development of partial risk guarantees, as in Mauritius, could be seen as an example.

\footnotetext{
${ }^{20}$ Islamic Globe, http://www.theislamicglobe.com/index.php?option=com_content\&view=article\&id=17:century-bankingcorporation-to-open-mauritius\&catid $=9$ :article $\&$ Itemid $=\overline{5} 3$

${ }^{21}$ Senegal and South Africa are expected to launch maiden sovereign issuance of sukuk (\$200 million and $\$ 500$ million, respectively) in the first half of 2014 (IFIS report and Zawya, December 2013).

${ }^{22}$ See "Mapping the Global Muslim Population" October, 2009, Pew Research Center. Washington DC; and "The Future of the Global Muslim Population" January 2011, Pew Research Center. Washington DC.

${ }^{23}$ The number of middle-class Africans has tripled over the past 30 years and amounts to about 34 percent of total population (African Development Bank, 2012).
} 
In addition, SSA countries could tap into growing Islamic financial markets to meet infrastructure financing needs. By opening doors to Islamic finance, SSA can seek to attract capital from the Gulf and other Muslim countries, whose savings rates are high and projected to grow significantly. In particular, sukuk financing, which is expanding in other countries, could be a useful tool to finance infrastructure investments.

Lastly, Islamic financing can help develop small and medium enterprises and microfinance activities, given that African households and firms have less access to credit from conventional banks compared to other developing regions. ${ }^{24}$ Islamic banks can tap a segment of depositors that either do not participate or do not trust interest-based banking. They can also promote SMEs' access to credit through expanding acceptable collaterals by extending funds on a participatory basis in which collateral is either not necessary or includes intangible assets (El Galfy, 2012).

\section{Developing Islamic Finance in Sub-Saharan AfRICA}

For those countries in SSA that are interested in introducing Islamic finance, one important issue to decide is the type of operations that would be available; this in turn helps identify the instruments and regulatory requirements. There are no strict templates, although the supply of different products should be designed on contracts and governance arrangements applying Shari'ah principles. ${ }^{25}$ The section deals with the following questions: How could Islamic finance products and frameworks be introduced? Should banking and other related laws be changed? Can conventional banks offer Islamic banking?

As noted in Section I, Islamic finance contracts provide a range of financial products and services to develop banking, nonbanking, insurance, and money and capital markets initiatives. In principle, any qualified financial intermediary can offer Islamic banking

\footnotetext{
${ }^{24}$ Demirgüç-Kunt and Klapper (2012) noted that despite the financial sector growth over the past decade, access remains limited. They also noted that cost, distance, and documentation requirements are important obstacles to promoting financial inclusion, though these barriers tend to ease as per capita income levels improve. In addition, these barriers tend to be lower in countries with more competitive, open, market oriented and well regulated financial systems. In SSA, only one-in-four adults have a formal bank account compared to nearly one-in-two adults having an account in other developing countries. Similarly, World Bank's enterprise surveys persistently reveal that access to credit, particularly for small and medium enterprises (SMEs), is a major obstacle in promoting growth and employment in SSA.

${ }^{25}$ These are: (i) prohibition of (riba), (ii) avoidance of preventable uncertainty and ambiguity in contracts (gharar) and gambling (maysir), (iii) ethical principles of justice, fairness, transparency, and public interest, including risk and profit sharing between involved partners, and (iv) a requirement that assets and investments can only come from, and be made in, Shari'ah compliant activities, where transactions are backed by tangible, identifiable underlying assets. All Islamic commercial jurisprudence are derived from the Qur'an, Sunnah (sayings of the Prophet).
} 
services, the key issue is the segregation of funds required to safeguard the interests of depositors and investors.

\section{A. Modalities}

Expanding on the classification advanced by Sole (2008), four forms for operations could be identified:

Islamic banking window. As the simplest form to provide Islamic banking services, a conventional bank can set up an Islamic window that allow banks customers to conduct business utilizing only Shari'ah compatible instruments, including deposits and Islamic trade-finance products for small and medium companies. A number of South East Asian and Western countries have opted for this vehicle to introduce Islamic services into their countries.

Islamic (full-fledged) Banking. In SSA, there are opportunities to establish Islamic subsidiaries or convert Islamic windows into full-fledged Islamic banks. ${ }^{26} \mathrm{~A}$ full-fledged Islamic bank might be better equipped to engage in Islamic investment banking activities, such as underwriting sukuk issuances or managing Shari'ah-compliant investments and hedge funds, or to manage its own treasury and money market operations. Sole (2008) emphasized that a subsidiary is usually a superior alternative as the parent bank may continue servicing its conventional customers, while the subsidiary expands its Islamic activities in clear separation from the conventional business. A full-fledged conventional banking conversion would signal the bank's firm commitment to operate under Shari'ah principlesthus enhancing its credibility - although it is not exempted from challenges, namely: ${ }^{27}$

- $\quad$ Operationally, the transition from conventional into Islamic transactions would require special attention to items in the banks' balance sheet that are subject to interest-bearing transactions. Several Islamic products - like ijara and Murabaha) have been designed to deal with these problems. In addition, the phasing in of Islamic instruments would need to be appropriately paced to maximize the benefits, while mitigating any potential risks.

\footnotetext{
${ }^{26}$ In October 2011, Qatar's regulator proposed extending its ban on onshore banks operating Islamic windows to include financial institutions in the Qatar Financial centre. The intention was to ensure a level-playing field for Islamic banks. Islamic windows present disadvantages due to the difficulties in properly separating capital, combining Basel and IFSB standards for capital adequacy, and supervising complex financial reporting given the overlapping nature of non-Islamic and Islamic activities. Moreover, Islamic windows complicate the preparation of financial reports governed by different standards and makes the comparative analysis of financial reports more difficult.
}

${ }^{27}$ In 2010, ABSA launched Islamic banking in Tanzania through its subsidiary the National Bank of Commerce (NBC), making its expansion into Africa. The NBC offers a checking and savings account. Tanzania launched its first Islamic bank, Amana Bank, in November 2011. 
- The supervisory burden is exacerbated as the regulator will be required to become familiar with the application of IFSB standards for Islamic banks.

Islamic Investment Banking. Banking systems worldwide have increased the offering of Islamic products and instruments to attract Shari'ah compliant investors. Benefiting from today's high cross-border capital mobility, instruments and tools for expanding Islamic investment banking in SSA include: sovereign and corporate sukuks and more sophisticated investment vehicles (such as Société Générale's pioneering Shari'ah-compatible hedge fund). ${ }^{28}$

Islamic Insurance. Takaful and retakaful represent forms of Islamic insurance and reinsurance based on principles of mutual assistance, burden-sharing and joint guarantees. Under these schemes, individuals pool resources with the agreement to use them only if there is a need. ${ }^{29}$

\section{B. Other Countries' Experience}

This section reviews the experience of European countries and Malaysia with Islamic finance. Such experience could be useful for African countries interesting in developing Islamic finance activities in their countries.

In Europe, the development of Islamic finance has focused on banking and capital markets through an explicit recognition of financial instruments and a provision for incorporation into tax codes. ${ }^{30}$ Luxembourg attracts Islamic funds from oil-rich countries and leads Europe in terms of Shari'ah-compliant investment funds and sukuk listed. The United Kingdom has managed to develop a supportive tax and legal environment, which provided impetus to the development of Shari'ah-compliant institutions based on the Murabahah principle. Today, the UK has become a centre for Islamic finance and most banks deliver Islamic finance with US\$19 billion of reported assets (Box 2). France allows compensation in sukuk to be treated as interest paid on any bond offering deductible from taxable income and exemption from withholding tax. In Italy and Germany, trade financing appears to be an important force behind Islamic finance and banking activities, either through foreign banks or by subsidiaries.

\footnotetext{
${ }^{28}$ Sukuk instruments are growing rapidly, with global sukuk issuance of US\$115 billion in 2013.

${ }^{29}$ According to the World Bank, while the number of African takaful companies is still limited, gross takaful contributions across the continent have exhibited an 18 percent compound annual growth rate between 2005 and 2008, and increased by 26 percent in 2009 to reach an estimated US\$377 million. Global takaful contributions reached an estimated US\$7 billion in 2009.

${ }^{30}$ European Central Bank (2013), Chapter 2.
} 


\section{Box 2. Development of Islamic Banking in the United Kingdom}

Although Islamic finance started in the UK in the 1980s, the industry took of after 2000. The first commodity Murabaha transactions and the first UK Islamic bank were launched in 1982. Most of these transactions involved Shari'ah compliant products, mostly in the areas of trade finance, leasing and project finance. In 2000, the Islamic banking industry received political and regulatory support that helped maintain momentum and strengthen the expansion of its activities through a working group led by the Bank of England, including representatives from the Treasury, FSA, the Council of Mortgage Lenders, financial institutions and members of the Muslim community. However, two major determinants facilitated the development of Islamic finance in the UK: the abolition of the double taxation regime in 2004 and the broad consutative process initiated by the UK authorities to clarify the regulatory treatment of corporate sukuk.

The implementation of Islamic banking in the United Kingdom comprised the following steps: (i) the abolishment of capital gains tax and stamp duty (land tax) for sukuk issuances and Shari'ahcompliant home mortgages; (ii) the reform of arrangements for bond issues to enable returns and income payments to be treated similarly to interest in conventional banking systems; (iii) legislation to ensure that the regulatory treatment of Islamic instruments is consistent with its statutory objectives and principles, and (iv) tax relief on Islamic mortgages extended to companies as well as to individuals.

In addition, particular attention was placed on the tax treatment of sukuk as they were seen as having significant potential for facilitating trade. The sukuk were structured along similar lines as conventional debt instruments: they do not pay interest but entitle investors to a share in the returns generated by the underlying asset.

Concomitantly, the UK authorities paid particular attention to develop Shari'ah scholarly capacity. Preparatory and instructional work was launched regarding Islamic finance and its instruments, and several universities introduced executive courses on Islamic finance. The UK also provided specialized legal services for Islamic finance, including areas of tax, compliance, regulations, management, operations, and information technology systems. Although the supervisory authorities in the UK are not aiming at promoting Islamic finance, they have set up a regulatory framework which is flexible enough to adapt to changes in the market. ${ }^{31}$

The development of Islamic finance in Malaysia into an internationally integrated financial system in which conventional and Islamic financial institutions work alongside each other is also highly relevant. Malaysia is considered a "hub" of Islamic finance and holds the world's largest Islamic bond market (Sukuk). ${ }^{32}$ The country has 20 Islamic banks, 16 Islamic windows, 9 Islamic Fund management companies, 8 Takaful companies, 4 re-takaful operators, and one international takaful operator. They represent close to one third of the

\footnotetext{
${ }^{31}$ See, Ainley et al (2007)

${ }^{32}$ In 2002, Malaysia hosted the establishment of the Islamic Financial Services Board (IFSB), in Kuala Lampur. The IFSB, comprising of international members, sets the standards for Islamic finance, aiming to ensure soundness and stability of the Islamic financial industry.
} 
financial institutions in Malaysia. The country also has Islamic Capital Markets, with a variety of products and investors, including nearly the majority of securities listed on the Malaysia Stock Exchange and 143 Islamic Unit Trust Funds. Sole (2008) classified the stages in this development as follows:

- In a first stage (1963), a small Islamic financial institution started operations by setting up Islamic savings fund, which managed small funds for individuals preparing for their pilgrimage to Mecca. ${ }^{33}$ The first Islamic bank (Bank Islam Malaysia Berhard) was granted a full-fledged banking license in 1983, following the enactment of the 1983 Islamic Banking Act in 1983, the establishment of a dispute settlements mechanism, and the issuing of Shari'ah compatible investment certificates - to facilitate liquidity management.

- In 1984, three conventional banks opened Islamic windows under certain restrictions (such as no commingling of funds). Building on their wide branch networks, conventional banks expanded Islamic products into larger segments of the population. In that same year, Bank Negara Malaysia established the Islamic Interbank Money Market allowing Islamic institutions to adjust their portfolios according to short-term financing needs.

- In a third stage, conversions into full-fledged Islamic banks became feasible whenever Islamic windows operated a critical mass of Islamic customers. A second full fledged Islamic bank (Bank Muamalat) was created in 1999 as a result of the merger between two Islamic windows, Bank Bumiputra and Bank of Commerce. In addition, Malaysia introduced the first inter-bank money market in 1994, facilitating liquidity management.

- In a final stage, Islamic Capital Markets were developed (2001) and several kinds of Islamic securities were issued and traded in secondary markets. In June 2005, the Dow Jones launched the Islamic Malaysia Index, which tracks over 45 Shari'ahcompliant companies. Also in 2005, the Malaysian Parliament approved the creation of the Perbadanan Insurans Deposit Malaysia (PIDM) to administer the deposit insurance system. The PIDM covers conventional and Islamic deposits alike, and it will undertake the resolution of failed conventional and Islamic banking institutions, when needed. Lastly, the International Finance Centre Initiative was launched in 2006, placing Malaysia at the core of the Islamic finance. ${ }^{34}$ This initiative is the

\footnotetext{
${ }^{33}$ Pilgrims' Fund Board (Lembaga Urusan Tabung Haji) has played a critical role in consolidating the activities of the small funds and eventually helped build the scale to spur demand for Shari'ah-compliant assets.

${ }^{34}$ www.thecityuk.com
} 
placeholder of Sukuk origination (with about one-half of the domestic bond market), Islamic fund and wealth management, and takaful.

\section{Developmental Strategies and Policy Issues}

A strategy to develop Islamic finance should be carefully tailored to the specific characteristics of the country, including, in particular, the size of the economy and its conventional financial system. At the same time, it becomes critical to strengthen capacity for domestic supervision, liquidity monitoring, and crisis management.

The introduction of Islamic banking entails a careful assessment of financial stability and appropriate legal, regulatory, and supervisory frameworks. Legal and prudential framework adjustments should include adequate but not preferential treatment for Islamic banks, and there should not be regulatory arbitrage. The objective is to ensure financial stability and establish a level-playing field for all banks (laws may unintentionally punish operations of Islamic banks).

Some SSA countries that are interested in developing Islamic finance activities could consider the following strategies to develop the Islamic finance:

- South Africa and Nigeria and aspiring service hubs like Mauritius or Seychelles which have the potential of becoming regional Islamic financial centers will need to ensure the introduction of international standards set by IFSB and AAOIFI and follow Shari'ah compliance.

- Most other countries are well-positioned to absorb the spirit of risk-sharing and profit-sharing of Islamic finance without being too rigidly constrained by Shari'ah compliance and could develop financial instruments in order to improve the access to finance for small and medium enterprises (SMEs). The business essence (risk sharing and profit sharing) of Islamic finance is very useful to provide finance to SMEs. Economies with strong religion requirements will likely be stricter about developing Islamic finance under Shari'ah compliance.

\section{All Markets}

- $\quad$ Strengthening accounting, auditing, and disclosure standards. In addition to the legal framework, strengthening accounting, auditing and disclosure standards for Islamic financial institutions and their counterparties, supported by adequate governance arrangements, enhances financial reporting and facilitates monitoring and assessment of Islamic financial institutions. The IFSB has developed a standard on Shari'ah governance systems and a transparency and disclosure framework to reflect the risk characteristics of Islamic financial institutions. In addition, the Accounting and Auditing Organization for Islamic Financial Institution (AAOIFI, created in 
1990s) disseminates accounting and auditing standards that can be applied internationally by all Islamic financial institutions.

- Strengthening property rights. Enforcing property rights and supporting private contracts through timely institutional reforms remain critical to strengthening financial deepening and develop Islamic as well as conventional banking.

- $\quad$ Capacity building. Islamic finance is a complex industry undergoing rapid product innovation but the number of people familiar with Islamic finance mechanisms is very small, highlighting the importance of building technical knowledge and skills. Collaboration and exchanges with leading countries such as Malaysia could be beneficial to help countries trying to develop Islamic finance build capacity with best practices and standards. ${ }^{35}$

- Implementation of prudential standards. The implementation of IFSB prudential standards is important for harmonization and to enhance the soundness of Islamic financial services. Several jurisdictions have implemented the prudential standards issued by the IFSB, which have been designed based on the unique features of Islamic finance. This should be supported by an assessment process to assist jurisdictions in evaluating their level of compliance with international standards and to make recommendations for improvements.

- Taxation. At a minimum, the tax system must not discriminate against the financial structuring required by Islamic finance with its emphasis on contracts, transactions and unwinding of positions. In addition, it would be desirable to have a level field between taxation of the proceeds from Islamic finance (profit) relative to interest. Similarly, business expenses related to Islamic Finance should be deductable for tax on the same basis as deductions for interest.

\section{Large Markets}

- Macro-prudential surveillance. It is important for countries developing Islamic finance to promote the Shari'ah-compliant macro prudential surveillance framework established by the Islamic Financial Services Board (IFSB). This would contribute to standardizing and reliable reporting of financial indicators and promote stability. ${ }^{36}$

\footnotetext{
${ }^{35}$ Recognizing the increasing relevance of Islamic finance in its territories, the UK has promoted the emergence of regional centers of excellence in Islamic finance through universities and business schools, including the areas of accounting, audit, and legal services (United Kingdom (2013)).

${ }^{36}$ Since its inception in 2002, the IFSB has the mandate to develop macro prudential and financial stability framework for the Islamic industry. The IFSB has also embarked on an initiative to establish a global database of prudential Islamic finance statistics.
} 
- $\quad$ Liquidity management. In many countries, Islamic banks in conventional systems have operated with no access to Shari'ah-compliant tradable short-term treasury instruments with which excess funds could be channeled to other Islamic banks. This restricted their growth and forced them to hold excessive reserves. In some cases, the absence of such instruments has also curtailed the central bank's ability to conduct monetary policy operations. The solution is to develop a Shari'ah- compliant (i) interbank market, (ii) a liquidity management facility/center, and (iii) a repo market.

- $\quad$ Financial safety nets. The financial safety net, namely, lender of last resort (LOLR) facilities and emergency financing mechanisms as well as deposit insurance, is a key component of a sound financial system. In the presence of significant Islamic finance activities, the financial safety net needs to be strengthened to comply with Shari'ah principles. However, this process is challenging. For example, the implementation of a well-designed Shari'ah compliant deposit insurance scheme is complicated because of the intricate funding structure of Islamic financial institutions (composed mainly of current accounts and unrestricted profit sharing and loss bearing investment accounts).

- Crisis management and resolution framework. Another important area is the development of a Shari'ah-compliant crisis management and resolution framework, which includes bank insolvency laws and the arrangements for dealing with nonperforming assets, asset recovery and bank restructuring, bankruptcy, as well as bank recapitalization. The challenges relate to the question of whether the conventional legal systems and common law jurisdictions adequately address, among other things, bank liquidation and insolvency issues arising from Shari'ah compliant financial transactions, for example, in terms of the priority of claims of depositors and shareholders during liquidation of an Islamic financial institution. ${ }^{37}$

\section{Concluding Comments}

Although Islamic finance in Sub-Saharan Africa is at a nascent stage, its potential lies on the size and expansion of its Muslim population and the concomitant expansion of Islamic finance activities in other parts of the world. The development of Islamic finance in SSA could usefully complement countries' efforts to deepen their conventional financial systems by broadening the range of available options, extend maturities, and facilitate hedging and risk diversification. In addition, Islamic financing can also contribute to the development of small and medium enterprises and microfinance activities.

\footnotetext{
${ }^{37}$ These risks are highlighted in the IFSB (2008).
} 
A number of countries in Sub-Saharan Africa have recently introduced or are considering introducing Islamic finance activities, including banking, Sukuk, Takaful (insurance) companies, and microfinance companies. Building on a need for fresh capital, countries are tapping investors to finance real estate and infrastructure projects on the heels of steady growth of Islamic finance, particularly via issuance of Sukuk.

Through its different forms — windows, full-fledged banking, investment banking, and Insurance-Islamic finance activities ensure appropriate leverage and help limit speculation and moral hazard. They are also subject to constraints and risks, most notably the difficulties and costs involved in supervising and monitoring and the reputational risk implicit in some products that are not properly certified as compliant with Islamic principles.

There are no strict templates for introducing Islamic finance activities into financial systems as a complement to conventional banking. In particular, experience shows that there is no need to introduce any Islamic Law to supersede conventional regulatory frameworks. However, it becomes critical to clarify ex ante issues pertaining to capital gains taxation for sukuk issuances and Shari'ah-compliant mortgages and, at the same time, build capacity to diffuse Shari'ah scholarly expertise.

A strategy to introduce Islamic banking activities could contemplate the following steps: launching a public awareness campaign, providing the needed infrastructure (i.e. amending as needed laws and accounting and prudential frameworks), building capacity at the central bank (especially on supervision), and considering the need to set up an appropriate liquidity management framework and introduce adequate monetary operations instruments.

As Islamic financing activities develop, regulators and financial institutions should familiarize themselves with the standards set by the AAOIFI and the IFSB, and apply them as needed. In particular, the IFSB has issued a whole spectrum of prudential and supervisory standards, which constitute the equivalent of Basel II in Islamic finance. ${ }^{38}$

In addition, as Islamic finance activities gain in importance and relevance, adapting the crisis management and resolution framework to the specific circumstances of Islamic finance becomes critical to ensure that any emerging crisis can be promptly managed.

To deepen the financial sector, policy makers may also want to develop new instruments that are inspired on Islamic finance principles, but not necessarily Shari'ah certified. Such instruments could appeal to a broader segment of the countries' population. At the same time, many SSA economies are characterized by shallow markets and narrow investors' bases, which suggests caution to avoid a proliferation of instruments and market fragmentation.

\footnotetext{
${ }^{38}$ IFSB et al. (2010).
} 
Lastly, the development of these activities beyond traditional banking within and across countries also creates a potential role for the Fund, both on the surveillance front as well as on the technical assistance area. This is especially important with respect to the design and implementation of prudential standards and rules that could facilitate a set of stable, efficient, and integrated Islamic finance activities. 


\section{REFERENCES}

Abedifar, Pejman, Philip Molyneux, and Amine Tarazi, 2013, "Risk in Islamic Banking" Review of Finance, vol. 17(6), January.

African Development Bank, 2012, "Islamic Finance: An Alternative Funding Source for the African Development Bank?” Africa Capacity Development Brief, Volume 3 (3): December.

Ainley, Michael, Ali Mashayekhi, Robert Hicks, Arshadur Rahman, Ali Ravalia, 2007, "Islamic Finance in the UK: Regulation and Challenges, FSA.

Alam, Nafis, 2012, “The Impact of Regulatory and Supervisory Structures on Bank Risk and Efficiency: Evidence from Dual Banking System," Asian Journal of Finance and Accounting, Volume 4, No 1.

Ariff, Mohamed, 1988, “Islamic Banking," Asian-Pacific Economic Literature, Volume 2, No 2 (September).

Arab News, 2009, "Nigeria Opens Market for Islamic Finance” April 13.

Buksh, Zhied, 2006, “Can Islamic Banking Work in South Africa?” MBA Thesis, Gordon Institute of Business Science (University of Pretoria, Pretoria).

Buksh, Zhied, 2006, “Can Islamic Banking Work in South Africa?” MBA Thesis, Gordon Institute of Business Science (University of Pretoria, Pretoria).

Chadbourne \& Parke LLP, 2013 "Islamic Bonds Go Mainstream”, October, available at http://www.chadbourne.com/IslamicBondsMainstream-Stevens_projectfinance/

Chapra, Umer, 2011, “The Global Financial Crisis: Some Suggestions for Reform of the Global Financial Architecture in the Light of Islamic Finance" Thunderbird International Business Review, Vol 53(4) September.

Cihák, Martin and Heiko Hesse, 2010, "Islamic Banks and Financial Stability: An Empirical Analysis," Journal of Financial Services Research. December 2010, Volume 38, Issue 2-3, pp 95-113.

Chong, Beng Soon, and Ming-Hua Liu, 2009, "Islamic Banking: Interest-free or Interestbased?" Pacific-Basin Finance Journal, 17: 125-144. 
Dow Jones Islamic Market Indexes, 2012, "The Challenges and Opportunities of Islamic Banking in Africa" Quarterly Newsletter, July.

Dridi, Jemma and Maher Hasan, 2011, "The effects of the global crisis on Islamic and conventional banks: a comparative study" Journal of Intl. Commerce, Economic, and Policy vol. 02, December.

Dusuki, Asyraf Wajdi, 2007, “The Ideal of Islamic Banking: A Survey of Stakeholders' Perceptions, Review of Islamic Economics, Special Issue, 11:29-52 (December).

El Galfy, Ahmed and Khiyar Abdalla Khiyar, 2012, "Islamic Banking and Economic Growth: A Review" The Journal of Applied Business Research, Vol 28(5), September.

El-Gamal, Mahmoud A., 2006, Islamic Finance: Law, Economics, and Practice (Cambridge, UK: Cambridge University Press).

European Central Bank, 2013, Islamic Finance in Europe, Occasional Paper Series, No 146, June 2013.

Gulf African Bank, 2010, "Islamic Finance: The African Experience (Growth, Potential, and Challenges), $2^{\text {nd }}$ East and Central African Islamic Finance Conference, Kenya (May, $3^{\text {rd }}$ and $\left.4^{\text {th }}\right)$.

Hesse, Heiko, Jobst, Andreas A., and Juan Solé, 2008, "Trends and Challenges in Islamic Finance," World Economics, Vol. 9, No. 2, pp. 175-93.

Ibrahim, Neimat Abdalla, 2010, "Islamic Banking Behavior Towards Small Firms Financing: Evidence from Sudan,” Khartoum University Journal of Management Studies, Volume 3, No 2.

Ilias, Shayerah, 2010, “Islamic Finance: Overview and Policy Concerns," Report for Congress, Congressional Research Service, RS22931 (Washington DC).

Imam, Patrick and Kangni Kpodar, 2010, “Islamic Banking: How Has it Diffused?” IMF Working Paper 10/195 (International Monetary Fund, Washington DC).

Iqbal, Zubair and Abbas Mirakhor, 1987, "Islamic Banking," Occasional Paper, No 49, International Monetary Fund (Washington DC).

Iqbal, Munawar and Molyneux, Philip, 2005, Thirty Years of Islamic Banking: History, Performance and Prospects, Palgrave Macmillan, UK. Pp. 190. 
Islamic Finance Stability Board, 2008, "Islamic Finance: Global Legal Issues and Challenges" at www.ifsb.org

Islamic Financial Service Board, 2010, Task Force on Islamic Finance and Global Financial Stability by the Islamic Financial Service Board, Islamic Development Bank, and Islamic Research and Training Institute. April (available at IFSB website).

Islamic Globe, 2012, "Century Banking Corporation to Open Mauritius" available on internet http://www.theislamicglobe.com/index.php?option=com content\&view=article\&id=1 7 :century-banking-corporation-to-open-mauritius \&catid=9:article \&Itemid $=53$.

Khaf, Monzer, Ausaf Ahmad, and Sami Homud, 1998, "Islamic Banking and Development: an Alternative Banking Concept?" Islamic Research and Training Institute (Islamic Development Bank, Jeddah).

Khan, Fahim M., 1983, "Islamic Banking as Practiced Now in the World" in Money and Banking in Islam, Ziauddin Ahmed, Munawar Iqbal, M. Fahim Khan (eds), International Center for Research in Islamic Economics, (Jeddah) and Institute of Policy Studies (Islamabad).

Khan, Feisal, 2010, “How 'Islamic' is Islamic Banking?” Journal of Economic Behavior and Organization, 76: 805-820.

Lewis, Mervyn, K., 2008, “In What Ways Does Islamic Banking Differ from Conventional Finance?" Journal of Islamic Economics, Banking and Finance, Volume 4, No. 3: 924.

Mohieldin, Mahmoud, 2012 Realizing the Potential of Islamic Finance, The World Bank, Washington DC.

Mirakhor, Abbas, and Krichene, Noureddine, 2009, "The Recent Crisis: Lessons for Islamic Finance" IFSB $2^{\text {nd }}$ Public Lecture on Financial Policy and Stability: 1-92.

Nienhaus, Volker, 1983, “The Performance of Islamic Banks: Trends and Cases," in, Islamic Law and Finance, Chibli Mallat (ed) (Page: 88-122).

Ndung'u Njuguna, 2011, "Islamic Finance—A Paradigm Shift in Africa," Remark by Professor Njuguna Ndung'u, Governor of the Central Bank of Kenya, at the 3rd Gulf African Bank Annual East and Central Africa Islamic Finance Conference, Nairo, March 28.

Opalesque (Islamic Finance Briefing), 2011, “Uganda Set for Islamic Banking,” February 16. 
Panapress, 2005, “Barclays Introduce Islamic Banking in Kenya,” December 20.

Pew Research Center, 2009, "Mapping the Global Muslim Population” Washington DC (October).

Pew Research Center, 2011,“The Future of the Global Muslim Population” Washington DC (January).

Solé, Juan, 2008, "Introducing Islamic Banks into Conventional Banking Systems," Journalof Islamic Economics, Banking and Finance, Vol. 4, No. 2. Also published as IMF Working Paper 07/175 (Washington: International Monetary Fund).

The City UK Group, 2013, "Islamic Finance Report," available at http://www.thecityuk.com/research/our-work/reports-list/islamic-finance-2013/

United Kingdom, 2013, “Excellence in Islamic Finance”, www.ukti.gov.uk/invest

Yaacob, Hakimahand others, 2011, International Convention for Islamic Finance: Towards Standardisation, ISRA Research Paper (NO. 29/2011). 